\title{
DESIRED DIMENSIONS OF PLACE BRAND PERSONALITY, INCLUDED IN ADVERTISING SLOGANS OF POLISH TOWNS/CITIES
}

\author{
Ewa Glinska ${ }^{1}$, Jaroslaw Kilon ${ }^{2}$ \\ ${ }^{1,2}$ Bialystok University of Technology, Poland \\ cross $^{\text {ref }}$ http://dx.doi.org/10.5755/j01.em.19.3.8375
}

\begin{abstract}
Cities compete to attract and retain residents, entrepreneurs and visitors. In order to achieve the competitive advantage local authorities use different concepts connecting with the process of branding in city management. One of them is brand personality which is treated as a very important component of the brand identity. The aim of this paper is to determine to what extent the content of an advertising slogan is linked to the town/city brand personality traits considered desirable by representatives of the local authorities of small and medium-sized cities in Poland. The study was based on a survey conducted on a sample of 220 cities and towns in Poland. The survey was made among managers dealing with promotion in the municipal offices in order to identify their desired brand personality traits of the city, in the design of which they were involved. It was proved that the association between the advertising slogan content and the set of declared personality traits describing a town/city exists regardless of the size of the town/city. In addition the degree of association between the slogan and the set of features describing desired town/city brand personality was estimated. It was indicated, that the attributes that were most commonly used in slogans usually belonged to the combination of the dimensions of excitement - competence sincerity. Conclusions from the research might be useful in developing the strategy of promotion of the city, and - more narrowly - in the creation of a promotional slogan being the shortest expression of the city brand identity.
\end{abstract}

The type of the article: Empirical study.

Keywords: city branding, city brand identity, city brand personality, city advertising slogan.

JEL Classification: M310.

\section{Introduction}

In today's world cities increasingly compete to attract and retain residents, entrepreneurs and visitors. As the location choice of people is based more and more on such soft factors as an area's image, most countries, regions and cities apply a strategy of place marketing (Hospers, 2004). At the start of the new millennium, the focus in the debate on place marketing shifted in the direction of place branding. According to Kavaratzis and Hatch (2013), place branding is becoming more and more popular, both, as a self-government practice, and as a research area. The branding of places (and cities in particular) has gained popularity among city officials, illustrated by the development of city brand rankings such as the Anholt-GMI City Brands Index or the Saffron European City Brand Barometer (Zenker \& Martin, 2011).

As a place branding is a relatively new academic area of inquiry, scholars are still finding their footing, borrowing theories and practices from other disciplines that include, but are not limited to, urban planning, corporate branding, marketing, public relations, sociology, psychology, management and organizational communication (Zavattaro, 2014). One of such ideas, coming from psychology, is the personality of the brand, which is starting to be used in the management of the place (Hosany, Ekinci \& Uysal, 2006).

It should be emphasized that the concept of brand personality belongs to the most fashionable in trends of marketing in the last decade. It is a kind of response to the growing importance of the 
non-functional properties of brands in consumer decision-making process as a reaction to the standardization of the functional properties and performance of different brands within a given product category (Gorbaniuk, 2011). This issue also applies to brand cities. Today, many cities and regions offer the same products and the only way to survive in a competitive market is to build a unique brand identity, based in particular on the non-functional components.

Analysis of the literature on the subject provide, that there is a large heterogeneity in the way of understanding of the concept of „brand personality" resulting from the different ways to conceptualize this idea. Some authors identify the brand personality as the brand image distinguishing it from the other brands, whereas the other ones narrow the understanding of brand personality only to the set of its non-functional characteristics of product. What is more, there is a group of authors who identify the brand personality with the image of the product (service) user (Gorbaniuk, 2011). Nevertheless, the most frequently cited definition of brand personality was proposed by Aaker (1997), who stated that the personality of the brand is ,a set of attributes or personal characteristics associated with the brand".

Undertaking the issue of personality of the brand is associated with the concept of its identity, which is defined by Aaker (1996) as ,an unique set of associations that the manager of the brand wants to create and maintain". From this managerial point of view, a place brand exists only if it is the result of a branding process which can be defined as designing, planning and communicating brand identity in order to build and manage a city image. Putting it simply, branding is the process of transition of the primary (existing, initial) city assets (identity) into a desired image (Florek, 2013). Many authors have conceptualized the notion of identity as multidimensional constructs, where the personality of the brand is a very important component, for instance Aaker and Joachimsthaler (2000) identify elements of the brand identity from four perspectives: the brand as a product, the brand as an organization, the brand as a person, and the brand as a symbol.

The brand personality is of particular importance to its image because it essentially reflects the emotional side of this conceptual category (according to Kaplan et al. (2010) the image covers, both, the emotional and the cognitive aspects associated with the brand). Therefore, identity refers to the sending party, and it defines the aspirations of the organization relating to the manner the brand is to be perceived. In turn, the brand image refers to the importance attached to the product by the consumers. It is basing on the experiences, impressions, and the perception of functional, emotional and symbolic benefits of the brand, and it impersonates the receiving party (Kaplan et al., 2010). Literature indicates that the image of the brand is imbedded in hard and soft associations caused by the product attributes (also a place), where the former refers to the material (e.g., functional or physical) properties, and the latter to the intangible features. The brand personality is based on "soft" (intangible) associations, and covers emotional side of the brand image (Biel, 1997).

Plummer (1985) defines the brand personality as a human personal characteristics attributed to the brand in order to facilitate communication of the physical elements and attributes of the brand in relation to the consumer. The same author (1985) emphasizes that the brand personality should be considered from two perspectives: the first - how the brand presents itself in the environment (brand identity, that is the sender's side), and the second - what is the current social perception (the brand image - recipient's side).

Cities all over globe include more and more marketing techniques in their administration practice and governing philosophy. The transfer of marketing knowledge, however, to the operational environment of cities creates some challenges, mostly due to the specific nature of places in general and cities in specific as marketable assets (Mahmoudzadeha, Nasra \& Hashemib 2014). Many places (also cities) in the world offers the same products and the only way for them to survive in the competitive market is developing a unique identity. Like product branding, place branding is a combination of place characteristics and of added value, functional and non-functional (Avraham \& Ketter, 2008). According to Ahmad et. al. (2013), nowadays the cities are keen to improve the image and brand value by maintaining their competitive edge. Some authors suggest 
that city brand personality is an essential element of a city brand; higher city brand personality creates an attractive brand.

The literature on the subject contains examples of the use of the concept of brand personality, which is usually applied in branding process of different categories of places, such as tourist destinations (e.g., Hosany et al., 2006), cities (e.g., Kaplan et al., 2010; Merriles, Miller \& Herington, 2009; Hee-Jung \& Yong-Gu, 2011; Usakli \& Baloglu, 2011; Ahmad, Abdullah, Tamam \& Bolong, 2013), regions (e.g., Murphy, Moscardo \& Benkendorff, 2007) or countries (e.g. Opoku, 2009). According to Gorbaniuk (2011), under the concept of interest in personality of territorial brands underlies a need for a universal tool to measure the image of the city / region / country that would abstract from the specific associations related to that territorial unit, and would allow for broader comparisons of different objects.

City branding has in recent years become a prevailing activity within city management. Cities all over the world use several tools to promote themselves to relevant audiences such as investors, visitors and residents and in their efforts they commonly include striking logos and captivating slogans that feature in welcoming websites and advertising campaigns in national and international media (Emirza \& Seri, 2013). Place managers should emphasize the uniqueness of their place and how this place alone can satisfy a certain need for the target audience. To achieve this aim, they use a slogan, logo, visual material and colours that vaunt the brand's spirit and promote its marketing (Avraham \& Ketter, 2008). The city advertisement slogan generally carries the essence of the place, trying to condense the marketing campaign into a pithy phrase. Good slogan is a powerful marketing tool that can reflect the place's vision, create enthusiasm and momentum, and should be identified with the place for many years (Avraham \& Ketter, 2008). To be effective slogan should be like desired image of the place, close to reality, believable, simple, appealing and distinctive (see: Kotler \& Gertner, 2004).

Slogan should be linked with the brand identity which, from the definition, is a basis for clear, unique and concise message that touches the consumer and provides him added value. An identity of the place brand, being the sending party, which defines the aspirations of the organization relating to the manner the brand is to be perceived, should be able to capture the reality of the place product and at the same time be strongly focused and able to express experiential (as opposed to functional) features of the cities (Moilanen \& Rainisto, 2009). According to Moilanen and Rainisto (2009), strong evidence exists suggesting that emotional factors may be more useful basis for brand identity development then functional features of the place product. In this situation, it is recommended that advertise slogan, which is one of the main tools of communication defined identity of a given place, also should refer to the intangible characteristics of place, including its personality, which covers emotional side of the brand image (see Biel, 1997).

In the context mention above, the purpose of this paper is to determine to what extent the content of an advertising slogan of given town/city is linked to the town/city brand personality traits considered desirable by representative of the local authorities of small and medium-sized cities in Poland. Due to the fact that cities are increasingly using non-functional aspects of the brand in the process of branding, the identification of the degree of using of desirable town/city brand personality traits (as an one element of its identity) in the process of building a recognizable image of place by their advertising slogans seems to be an important research problem. The desire to capture the differences between the cities in terms of the degree of relationship between content of slogan and the desired traits of the city personality, as well as to determine to what extent the various dimensions of brand personality are used in these slogans were the additional motivation of the paper.

\section{Method}

To achieve these objectives it was decided to carry out the surveys among managers dealing with promotion in the municipal offices in order to identify their desired brand personality traits of the city, in the design of which they are actively involved. Such an approach to identify the personality dimensions used in the process of building a brand is justified in the opinion of 
Plummer (1985), according to which brand personality can be seen not only from the point of view of the recipient, but also from the perspective of the sender, which means to identify how the brand presents itself to the environment. In this study the first perspective was assumed. This approach is a certain novelty in research on the brand personality of the city, as earlier studies were carried out to identify the manner of perception of the dimensions of brand personality from the perspective of the recipient.

The study was conducted on a comprehensive sample, which means it included the population of Polish cities with the population of no less than 10 thousand residents and not more than 200 thousand (a total of 379 cities). The research was carried out simultaneously with the use of the mail survey technique and the CAWI technique. The survey was based on a standardized questionnaire, that contained 18 questions, of which the vast majority (approx. 90\%) were closed questions. However, due to the qualitative nature of certain aspects of the brand of the city (especially when the personality of a city was concerned) it was decided to ask additional, open questions. Such an approach allowed authors to define and analyze a number of quantitative variables, that were well placed in the qualitative research context. Finally, 220 completed questionnaires were received, which were further analyzed. It is worth to mention, that the results presented in this article are just a part of a wider research project that serves as a basis for other scientific analysis.

In the questionnaire respondents were asked to freely declare the descriptors (adjectives) that describe the desired image of the city in the categories that are usually attributed to people (If you had to describe the desired image of the city in terms of features / adjectives that are usually attributed to humans, what would be the characteristics?). The question was asked in the open form, because it was assumed that such uninhibited manner of data collection will not restrict the declared personality traits of the city solely to the suggested list. The qualitative analysis of the answers given by respondents to this open question included both the management of data collected from the research, as well as their interpretation. During a further stage of work on the resulting list of adjectives characterizing the desirable personality traits of city brands, it was decided to assign them to the brand personality dimensions identified by Aaker (1997): sincerity, excitement, competence, sophistication, and roughness. The assignment procedure was subjective in nature, based on the knowledge and intuition of the authors of the article, which should be treated as one of the limitations of the interpretation of the obtained results.

In addition, the content analysis of the slogans of the cities in their marketing activities declared by the managers of promotion within the same research project was made. Content analysis is a technique used in the analysis of texts of various types (Neuman, 2003, cited in: Pitt et al., 2007). This method is useful in studies carried out in the social sciences framework, especially in the areas related to advertising and promotion (Kolbe \& Burnett, 1991, cited in: Pitt et al., 2007). During that part of the study 156 slogans were analyzed, of which 126 were considered as related to the brand personality dimensions. All of the slogans were specified by respondents of the survey in response to a question from the questionnaire.

As a result, an attempt to estimate the degree of association between the slogan and the set of features describing the same town/city brand personality desired by promotion managers of the municipal offices was undertaken according to the following formula:

strength of association $=$

Source: authors number of indicated town/city's personality traits used in the slogan of given city number of indicated town/city personality traits declared by representative of the local authorities in reply to question: If you had to describe the desired image of the city in terms of features / adjectives that are usually attributed to humans, what would be the characteristics?

In the above relationship, the indicator can take a value from 0 (in the case of no personality traits are used in the slogan) to 1 (when all personality traits indicated by the respondent are contained in the promotional slogan of the town/city). In the interpretation, the thresholds indicated in Table 1 were adopted. 
Table 1. The way of identification the degree of use of desirable town/city brand personality traits in advertising slogans

\begin{tabular}{|c|c|}
\hline Strength of association & $\begin{array}{c}\text { Degree of association: } \\
\text { desirable personality traits of town/city brand } \leftrightarrow \text { advertising slogan }\end{array}$ \\
\hline$(0 ; 0.33>$ & Low \\
\hline$(0.33 ; 0.67>$ & Moderate \\
\hline$(0.67 ; 1>$ & High \\
\hline
\end{tabular}

Source: authors calculations.

\section{Results}

The respondents were asked to freely declare some descriptors (adjectives) that describe the desired image of a city brand in terms that are usually attributed to human being. Participants of the study indicated up to five adjectives relating to the represented cities. A total of 873 adjectives were indicated, of which quite a large group repeated in various cities. Afterwards, the list of adjectives was reduced to 190 and they were assigned to the brand personality dimensions identified in a study by Aaker (1997).

A fairly large group of city descriptions declared by the respondents (about $78 \%$ ) could be qualified as belonging to the scale of the brand personality dimensions by Aaker (1997) (in some cases the attributes classified as belonging to a given dimension were not identical to those in that scale, but showed similar / synonymous meaning). They have been called universal dimensions (fig. 1). Most descriptions fell into the dimension of „excitement” and „,competence“. Quite often the cities want to be perceived as sincere (dimension of ,sincerity”). Almost every tenth term regarding the desirable traits of the personality of the city can be qualified as part of the dimension of „sophistication“. It is interesting that, as in the earlier studies concerning the personality of the brands of locations, the dimension of ,ruggedness" from the Aaker scale did not apply in relation to the city. More than $20 \%$ of the obtained attributes could not be qualified as part of the dimensions of the personality of the brands, developed by Aaker, therefore, three additional ones were distinguished (so called ,specific dimensions”). Among them there are such as attributes as: peace, neatness, or conservatism. The appearance of these extra dimensions is associated with the fact that the city is a very complex product, which raises more associations than the classic product.

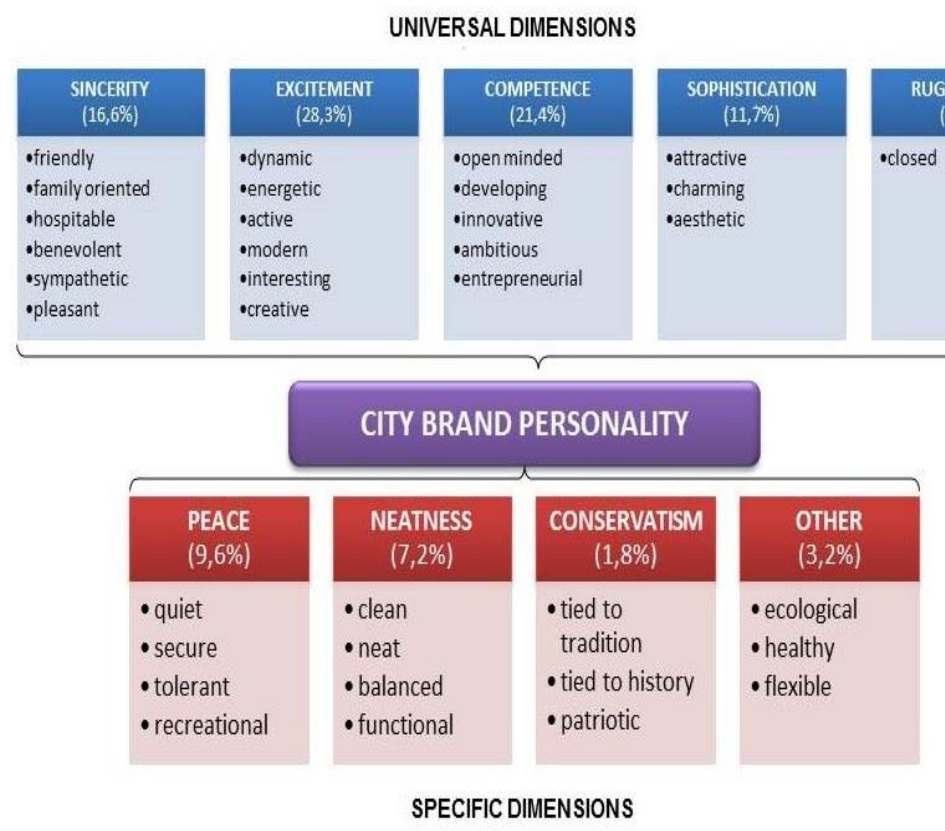

Figure 1. Dimensions of desired brand personality of the city with examples of the most common characteristics declared by respondents

Source: Glińska, E. \& Kilon, J. (2014). Desirable traits of the city brand personality in the opinion of managers for the promotion of the city government in Poland, Procedia - Social and Behavioral Sciences, in publishing process. 
Respondents were also asked to indicate whether or not their town/city uses an advertising slogan in its promotional activities. According to the results, over $71 \%$ of the respondents admitted that advertising slogans were used in the promotional activities of the towns/cities they represented. The use of advertising slogans in activities related to building the desired town/city image turned out to be dependent on the town's size expressed by its population. The larger the towns/cities, the more frequent the use of advertising slogans in their information and promotion activities.

Table 2. The use of a slogan in town/city promotional activities in towns/cities of different size

\begin{tabular}{|c|c|c|c|}
\hline \multirow{2}{*}{$\begin{array}{c}\text { Town/city } \\
\text { Population }\end{array}$} & No & Yes & \multirow{2}{*}{ Overall sum } \\
\cline { 2 - 3 } & $28.9 \%$ & $71.1 \%$ & $100.0 \%$ \\
\hline below 15 thousand & $40.2 \%$ & $59.8 \%$ & $100.0 \%$ \\
\hline 15-25 thousand & $20.0 \%$ & $80.0 \%$ & $100.0 \%$ \\
\hline $25-50$ thousand & $15.4 \%$ & $84.6 \%$ & $100.0 \%$ \\
\hline over 50 thousand & $28.8 \%$ & $71.2 \%$ & $100.0 \%$ \\
\hline Total & &
\end{tabular}

Test of independence: chi-square $=11.05 ; \mathrm{p}=0.011$

Source: authors calculations.

The association between the use of a slogan in promotional activities and the size of the town/city is statistically significant.

Using the technique described in part „method”, an attempt was undertaken to estimate the degree of association between the slogan and the set of features describing town/city brand personality desired by promotion managers of the municipal offices. The data in the Table 3 show that for every third town/city, the degree of association between the town/city brand's declared desirable personality traits and the content of its advertising slogan is high. For nearly $44 \%$ of the towns/cities, the degree of association is moderate. Low degree of association was identified in approximately $22 \%$ of the surveyed towns/cities.

Table 3. Distribution of the towns/cities according to the degree of use of desirable town/city brand personality traits in advertising slogans

\begin{tabular}{|l|c|}
\hline \multicolumn{1}{|c|}{$\begin{array}{c}\text { Degree of association: } \\
\text { desirable personality traits of town/city brand } \leftrightarrow \text { advertising slogan }\end{array}$} & $\begin{array}{c}\text { Percentage of the } \\
\text { towns/cities }\end{array}$ \\
\hline Low & $22.2 \%$ \\
\hline Moderate & $43.7 \%$ \\
\hline High & $34.1 \%$ \\
\hline
\end{tabular}

Source: authors calculations.

The association between the advertising slogan content and the set of personality traits describing a town/city and declared by promotion managers from municipal offices exists regardless of the size of the town/city (Table 4). The degree of this association is, however, the highest in the case of large towns/cities, and is the lowest in the case of towns with population up to 15 thousand. The association may still be described as a universal phenomenon (the relationship between the size of a town/city and the association of its slogan with the set of its personality traits is not statistically significant). 
Table 4. Use of personality traits in town/city's promotional slogan, against the size of the town/city (in the group of towns/cities which use slogans)

\begin{tabular}{|c|c|c|c|}
\hline \multirow{2}{*}{$\begin{array}{c}\text { Town/city } \\
\text { population }\end{array}$} & $\begin{array}{c}\text { Association between slogan content and declared } \\
\text { personality traits of town/city brand }\end{array}$ & \multirow{2}{*}{ Total } \\
\cline { 2 - 3 } & no association & associated & \\
\hline below 15 thousand & $25.9 \%$ & $74.1 \%$ & $100.0 \%$ \\
\hline 15-25 thousand & $19.2 \%$ & $80.8 \%$ & $100.0 \%$ \\
\hline $25-50$ thousand & $25.0 \%$ & $75.0 \%$ & $100.0 \%$ \\
\hline over 50 thousand & $6.1 \%$ & $93.9 \%$ & $100.0 \%$ \\
\hline Total & $19.2 \%$ & $80.8 \%$ & $100.0 \%$ \\
\hline
\end{tabular}

Test of independence: chi-square $=5.41 ; \mathrm{p}=0.144$

Source: authors calculations.

Similar conclusions can be drawn while attempting to identify the relationship between the size of a town/city and the degree of association between the slogan content and the town/city brand personality traits declared as desired by promotion managers from municipal offices (Table 5).

Table 5. Degree of use of personality traits in town/city's promotional slogan, against the size of the town/city (in the group of towns/cities which use slogans, where such association exists)

\begin{tabular}{|c|c|c|c|c|}
\hline \multirow{2}{*}{$\begin{array}{c}\text { Town/city } \\
\text { population }\end{array}$} & Low & medium & high & \multirow{2}{*}{ Total } \\
\cline { 2 - 5 } $\begin{array}{c}\text { below 15 } \\
\text { thousand }\end{array}$ & $35.0 \%$ & $45.0 \%$ & $20.0 \%$ & $100.0 \%$ \\
\hline $15-25$ thousand & $21.4 \%$ & $42.9 \%$ & $35.7 \%$ & $100.0 \%$ \\
\hline $25-50$ thousand & $18.2 \%$ & $42.4 \%$ & $39.4 \%$ & $100.0 \%$ \\
\hline $\begin{array}{c}\text { over 50 } \\
\text { thousand }\end{array}$ & $19.4 \%$ & $45.2 \%$ & $35.5 \%$ & $100.0 \%$ \\
\hline Total & $22.2 \%$ & $43.7 \%$ & $34.1 \%$ & $100.0 \%$ \\
\hline
\end{tabular}

Test of independence: chi-square $=2.66 \mathrm{p}=0.850$

Source: authors calculations.

Notably, among the towns/cities with a low degree of association between the slogan content and the town/city brand personality traits declared as desired by promotion managers from municipal offices, the largest percentage are small towns with population up to 15 thousand. In the group of towns/cities with a high degree of association between the two variables, towns with up to 15 thousand inhabitants make up the smallest percentage.

Cities participating in the study refer to the various dimensions of brand personality in their promotional slogans in a relatively high degree. The attributes that are most commonly used in slogans belong to the combination of three dimensions: excitement, competence and sincerity (tab. 6). This combination is consistent with the overall incidence of the brand personality dimensions indicated as a desired image of the studied cities.

Table 6. Dimension of city brand personality used in promotional slogan

\begin{tabular}{|l|c|c|c|c|}
\cline { 2 - 4 } \multicolumn{1}{c|}{} & \multicolumn{2}{c|}{$\begin{array}{c}\text { Association between slogan content and declared } \\
\text { personality traits of town/city brand }\end{array}$} & $\begin{array}{c}\text { Total in the group of } \\
\text { towns/cities which } \\
\text { use slogans }\end{array}$ \\
\cline { 2 - 4 } \multicolumn{1}{c|}{ Low } & medium & High & $47.4 \%$ \\
\hline Excitement & $28.6 \%$ & $39.2 \%$ & $66.7 \%$ & $43.9 \%$ \\
\hline Competence & $23.8 \%$ & $47.1 \%$ & $50.0 \%$ & $41.2 \%$ \\
\hline Sincerity & $19.0 \%$ & $43.1 \%$ & $50.0 \%$ & $24.6 \%$ \\
\hline Sophistication & $23.8 \%$ & $19.6 \%$ & $31.0 \%$ & $13.2 \%$ \\
\hline Peace & $0.0 \%$ & $11.8 \%$ & $21.4 \%$ & $6.1 \%$ \\
\hline Neatness & $0.0 \%$ & $2.0 \%$ & $14.3 \%$ & $5.3 \%$ \\
\hline Other & $0.0 \%$ & $3.9 \%$ & $9.5 \%$ & $2.6 \%$ \\
\hline Conservatism & $4.8 \%$ & $3.9 \%$ & $0.0 \%$ & \\
\hline
\end{tabular}

* Slogan can be linked with many dimensions.

Source: authors calculations. 
When the context of the degree of integration between the content of slogan and personality attributes of a city is concerned, the analysis of the differences in the utilization of individual personality dimensions leads to additional applications: in the cities where there is a strong integration, the slogans are used primarily to determine the „excitement" dimension. When the degree of relationship decreases such dimensions as „competence“ and „sincerity“ become more and more important. Finally, in the case of the weakest link „sophistication“ dimension is used. Some specific dimensions (i.e. „conservatism“) are used in the smallest range, as they are often characterized pejoratively or relate to a narrow group of potential customers.

\section{Discussion}

The promotional slogans are the most widely used for image creation in branding strategy of the largest cities (counting 25 thousand and more inhabitants), which may result from more comprehensive approach to the issue of branding (i.e. the larger budget or having competent employees, conscious of such need). At the same time, however, the possession and use of the slogan for the image and brand building activities, often characterized the smallest towns, for which the slogan can be one of the key components of the differentiation strategy. The degree of association between desirable personality traits of town/city brand and the content of its advertising slogan is rather moderate and high in the case of Polish cities, which is one of the of the indicator of using non-functional features of the city in the process of its branding. Cities often refer to various dimensions of brand personality in their promotional slogans, usually exploiting the attributes belonging to the dimensions of excitement, competence and sincerity, whereas the specific dimensions (i.e. „conservatism“) are rarely used.

Conclusions from the research might be useful in developing the strategy of branding the city, and - more narrowly - in the designing of a promotional slogan being the shortest expression of the city brand identity. The results are valid also from a cognitive point of view, because the development of theory in place branding is at an early stage. Undertaking the research themes that have evolved in this area is crucial, as these help create the foundation to better appreciate place brand identity. A particularly important role plays the concept of brand personality, as, according to Ruzzier and Chernatony (2013), in the past, place marketing/branding strategies centred primarily on functional attributes such as the beauty of particular environments, advanced infrastructures, etc., but recently, the focus of place marketing has shifted to promoting emotional and experiential attractions.

\section{Acknowledgements}

Research study financed from funds for science in the years 2010-2013 as research project No. N N115 155939 Identification of city identity markers and analysis of the degree to which they are used in city image management in Poland.

\section{References}

Aaker, D. A. (1996). Building strong brands, New York: The Free Press.

Aaker, D. \& Joachimsthaler, E. (2000). Brand leadership. New York: The Free Press.

Aaker, J. (1997). Dimensions of brand personality. Journal of Marketing Research, 34 (3), 347-356. http://dx.doi.org/10.2307/3151897

Ahmad, M. F., Abdullah, Z. B., Tamam, E. B. \& Bolong, J. B. (2013). Determinant Attributes of City Brand Personality that Influence Strategic Communication. Canadian Social Science, 9, 2, 40-47. doi: 10.3968/j.css.1923669720130902.9002

Avraham, E. \& Ketter, E. (2008). Media strategies for marketing places in crisis. Improving the image of cities, countries and tourist destinations, Oxford: Elsevier.

Biel, A. L. (1997). Discovering brand magic: the hardness of the softer side of branding. International Journal of Advertising, 16, 3, 199-210. 
Emirza, E. \& Seri, İ. (2013). The Measurement of Brand Personality in the City Brand: a Case of Kayseri, In International Conference on Economic and Social Studies, 10-11 May, 2013, Sarajevo, 1 (1), 168-179. Retrieved from http://eprints.ibu.edu.ba/1567/

Florek, M. (2013). Links between city brand identity and positioning: implications for the communication strategy, In Proceedings of International City Branding Symposium 2013. Positioning Cities: Innovative and Sustainable Strategies for City Development and Transformation, October 23-25, 2013, Beijing, China, 136-152. Retrieved from

http://www.tsjc.tsinghua.edu.cn/publish/jc/245/20140716143815066121782/a.pdf

Glińska, E. \& Kilon, J. (2014). Desirable traits of the city brand personality in the opinion of managers for the promotion of the city government in Poland, Procedia - Social and Behavioral Sciences (in publishing process).

Gorbaniuk, O. (2011). Personifikacja marki. Perspektywa psychologiczna i marketingowa, Lublin: KUL.

Hosany, S., Ekinci, Y. \& Uysal, M. (2006). Destination image and destination personality: An application of branding theories to tourism places. Journal of Business Research, 59, 638-642. doi:10.1016/j.jbusres.2006.01.001

Hospers, G. J. (2004). Place marketing in Europe the branding of the Oresund Region, Intereconomics September/October, 39 (5), 271-279. doi: 10.1007/BF03031785

Kaplan, M. D., Yurt, O., Guneri, B. \& Kurtulus, K. (2010). Branding places: applying brand personality concept to cities. European Journal of Marketing, 44, 9/10, 1286-1304. doi: 10.1108/03090561011062844

Kavaratzis, M. \& Hatch, M. J. (2013). The dynamics of place branding: an identity-based approach to place branding theory. Marketing Theory, 13 (2), 69-86. doi: 10.1177/1470593112467268

Kolbe, R. H. \& Burnett, M. S. (1991). Content analysis research: An examination of applications with directives for improving research reliability and objectivity, Journal of Consumer Research, 18.

Konecnik Ruzzier, M., de Chernatony, L. (2013). Developing and applying a place brand identity model: The case of Slovenia. Journal of Business Research 66, 45-52. doi:10.1016/j.jbusres.2012.05.023

Kotler, Ph. \& Gertner, D. (2004). Country as brand, product and beyond: a place marketing and brand management perspective. In N. Morgan, A. Pritchard, \& R. Pride (Eds.), Destination Branding: Creating the Unique Destination Proposition pp. 40-56. Oxford: Elsevier Butterworth-Heinemann.

Mahmoudzadeh, S. M., Nasr, M. S. \& Hashemi, M. (2014). A survey on factors influencing city branding. Management Science Letters 4. doi: 10.5267/j.msl.2014.9.001

Moilanen, T. \& Rainisto, S. (2009). How to brand nations, cities and destinations. A planning book for place branding, New York: Palgrave Macmillan.

Murphy, L., Benchendorff, P. \& Moscardo, G. (2007). Destination Brand personality: visitor perceptions of a $\begin{array}{lllll}\text { regional tourism } & \text { destination. } & \text { Tourism }\end{array}$ http://dx.doi.org/10.3727/108354207783227948

Neuman, W. L. (2003). Social research methods-qualitative and quantitative approaches (5th ed.), Boston: Pearson Education.

Opoku, R. A. (2009). Mapping Destination Personality in Cyberspace: An evaluation of Country Web Sites Using Correspondence Analysis. Journal of Internet Commerce, 8 (1-2), 70-87. doi:10.1016/j.tourman.2006.06.003

Pitt, L. F., Opoku, R., Hultman, M., Abratt, R. \& Spyropoulou, S. (2007). What I say about myself: Communication of brand personality by African countries, Tourism Management 28.

Plummer, J. T. (1985). How Personality Makes a Difference. Journal of Advertising Research, 24, 6, 27-31.

Zavattaro, S. M. (2014). Place branding through phases of the image: balancing image and substance, New York: Palgrave Macmillan. http://dx.doi.org/10.1057/9781137394514

Zenker, S. \& Martin, N. (2011). Measuring success in place marketing and branding. Place Branding and Public Diplomacy, 7(1), 32-41. doi: 10.1057/pb.2011. 